\title{
A Spectrophotometric Study of the Thorium-Morin Mixed-Color System
}

By Mary H. Fletcher and Robert G. Milkey

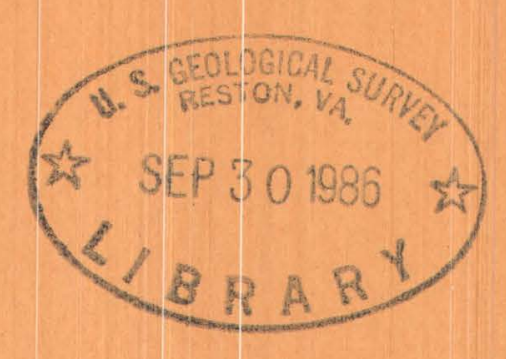

\section{Trace Elements Investigations Report 460}

And. Chemistry, 178, no.9, p.1102-1407, 1906.

UNITED STATES DEPARTMENT OF THE INTERIOR GEOLOGICAL SURVEY 
Chemistry

This document consists of 40 pages. Series A.

UNITED STATES DEPARTMENT OF THE INTERIOR

GEOLOGICAL SURVEY

A SPECTROPHOTOMETRIC STUDY OF THE THORIUM-MORIN

MIXED-COLOR SYSTEM*

By

Mary H. Fletcher and Robert G. Milkey

October 1954

Trace Elements Investigations Report 460

Anal. Chementy, 0.28, 20, $20.1402-1407,956$.

This preliminary report is distributed without editorial and technical review for conformity with official standards and nomenclature. It is not for public inspection or quotation.

*This report conceras work done on behalf of the Division of Raw Materials of the U. S. Atomic Energy Comission. 
USGS - TEI-460

CHEMISTRY

Distribution (Series A)

Argonne National Iaboratory 00000000000000000000000000000000. I

Atowic Energy Comnission, Washington 0.0000000000000000000000 2

Battelle Memorial Institute, Columbus .000000000.0000000 I

Carbide and Carboi Chemicals Company, Y-12 Area oo oo oo o.

Division of Raw Materials, Albuquerque 000000000000000000000001

Division of Raw Materials, Butte 0000000000000000000000000000 I

Division of Raw Materials, Deaver a00000000000000000000000000 I

Division of Raw Materials, Douglas 000000000000000000000000000. I

Division of Raw Materials, Hot Springs 0000000000000000000000 I

Division of Raw Materials, Ishpeming o000000000000000000000 I

Division of Ray Materials, Phoenix o000000000000000000000000000 I

Division of Ray Materials, Richileld o00000000000000000000000 I

Division of Raw Materials, Salt Lake City o0000000000000000. I

Division of Raw Materials, Washington 00000000000000000000000 3

Division of Researeh, Washington, 000000000000000000000000000. I

Dow Chemical Company. PIttsburg 0000000000000000000000000000000 I

Exploration Division, Grand Junction Operations Office a. o. I

Grand Junction Operations Office o0000000000000000000000000000 I

National Lead Company, Winchester oo0000000000000000000000000 I

Technical Information Service, Oak Ridge o000000000000000000006

Tennessee V2.1.1ey Authority, Wilson Dam 0000000000000000000000 1

U. S, Geological Survey:

Alaskan Geology Branch, Menlo Park 0000000000000000000000000000 I

Fuels Branch, Washington 00000000000000000000000000000000000000 1

Geochemistry and Petrology Branch, Washington o0000000000000020

Geophysics Branch, Washington 000000000000000000000000000000001

Mineral Deposits Branch, Washington 000000000000000000000000001

E. Ho Baileyg Menlo Park 00000000000000000000000000000000000000 I

A. La Brokaw, Grand Junction 000000000000000000000000000000000 I

Io Ro Cooper, Denver 00000000000000000000000000000000000000000. I

No. Mo Denson, Denver 000000000000000000000000000000000000000000 I

Co E. Dutton, Madison 00000000000000000000000000000000000000000 I

W Lo Emerick, Plant CIty 0000000000000000000000000000000000000 I

I. S. Cardner, Albuquerque 0000000000000000000000000000000000001

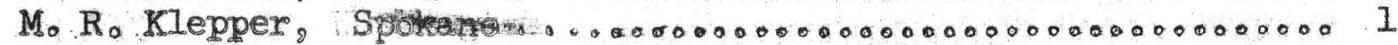

A. Ho Kos chwand, Denver 000000000000000000000000000000000000000 I

$R_{0}$ A. Lqureaceg Knoxille 0000000000000000000000000000000000 I

$D_{0} M_{0}$. Lemon, Washington 00000000000000000000000000000000000000 I

Jo Da Love, Laramie 000000000000000000000000000000000000000000 I I

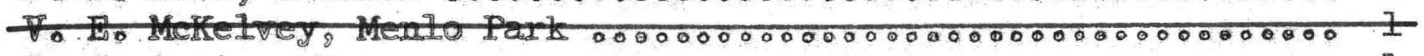

P. Co.Patton, Deaver 000000000000000000000000000000000000000000 I

$J_{0} F_{0}$ Powerg, Salt Iake City 00000000000000000000000000000001

Q. D. Singewald, Belt5vilIe 00000000000000000000000000000000000 I

Jo.Fo Smith, Jro, Denver 00000000000000000000000000000000000000 I

A. Eo. Welssenborn, Spokane 00000000000000000000000000000000001

TEPCO, Denver 0000000000000000000000000000000000000000000000003/

TEPCO, RPS, Washington (Including master) 0000000000000000000 2 
CONTENTS

Page

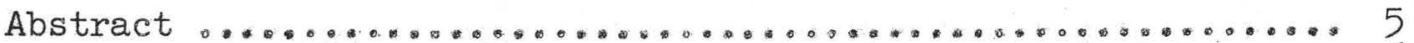

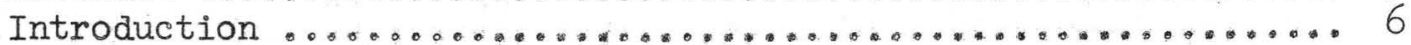

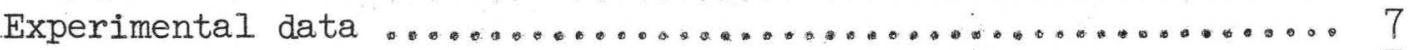

Apparatus and reagents .............................. 7

Determination of conditions for maximum sensitivity and/or

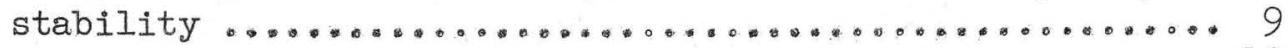

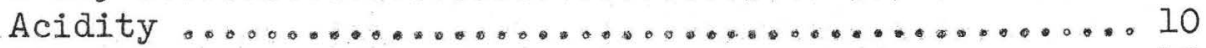

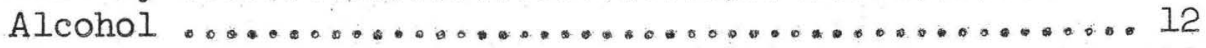

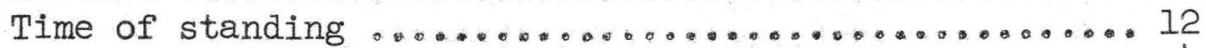

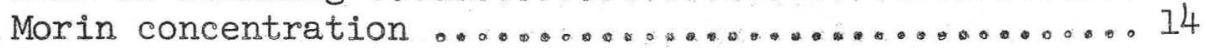

Age of morin reagent solution ................. 17

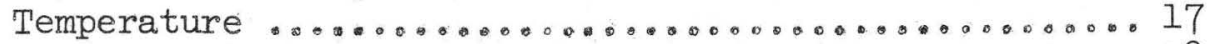

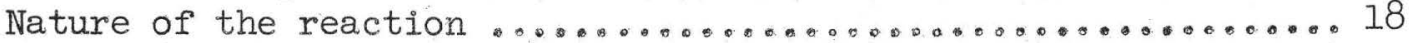

Determination of the composition of the complex .............23

Determination of components of any solution and calculation of

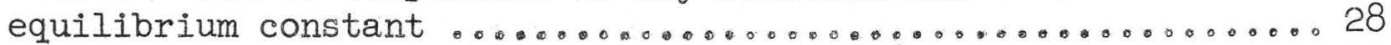

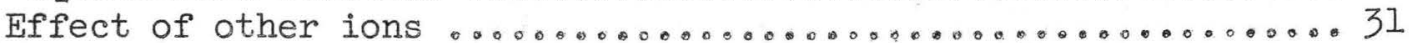

Detailed procedure for the determination of thorium in pure

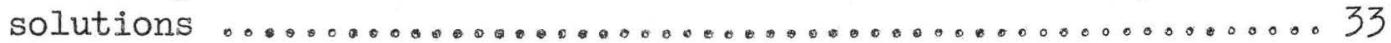

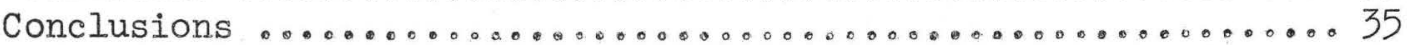

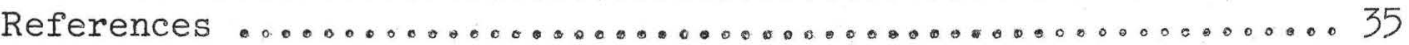

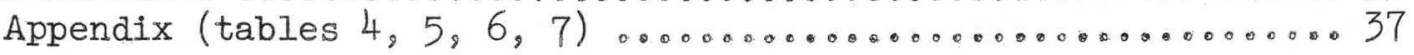

ILLUSTRATIONS

Page

Figure 1. Spectrophotometric curves of solution of thorium and morin (B) and pure morin (A) ............ 8

2. Effect of acidity on absorbance at $410 \mathrm{~m} / \mathrm{f}$ for pure morin (1); morin plus thorium (2) .............

3. Effect of alcohol concentration on absorbance at $410 \mathrm{~m} /$ for pure morin (1) and morin plus thorium

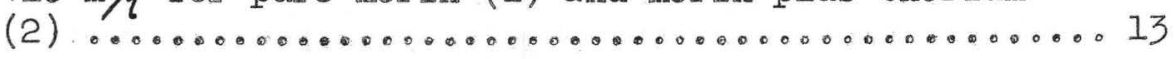

4. Effect of time of standing on absorbance ......... 15

5. Effect of morin concentration .................. 16

6. Effect of temperature on absorbance ............. 19

7. Spectrophotometric curves showing isobestic point ...21 
Figure 8. Absorbance at $410 \mathrm{~m} / \mu$ as a function of thorium concentration o.0.00000000000000000000000.22

9. Determination of composition of the complex by the method of continuous variations .............. 24

10. Determination of composition of complex by slope-

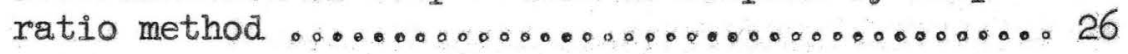

11. Absorptivity of morin $00000000 \ldots 0 \ldots 00 \ldots \ldots \ldots 29$

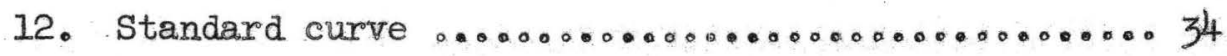

\section{TABLES}

Page

Table 1. Effect of age of morin reagent on absorbance measurements 0000000000000000000000000000000000018

2. Weight of various substances in $50 \mathrm{ml}$ of solution which are equivalent to an absorbance difference of 0.010 at $410 \mathrm{~m} \mu$ when measurements are made in a 5-cm cell o000000000000000000000000000000000000031

3. Weight ratio of interfering substance to $\mathrm{ThO}_{2}$ for 90 percent accuracy in determination of $\mathrm{ThO}_{2} \ldots \ldots .32$

4. Apparent equilibrium constant with the morin concentration the same for all solutions $\left(3.548 \times 10^{-5}\right.$ moles per liter) and the concentration of thorium varying 000000000000000000000000000000000000000003 37

5. Apparent equilibrium constant with the thorium concentration the same for all solutions $(0.3809 \mathrm{x}$ $10^{-5}$ moles per liter) and the concentration of morin varying 0000000000000000000000000000000000000 38

6. Apparent equilibrium constant with the concentration of thorium and morin both varying con tinuously. Total moles Th + morin constant .00000 39

7. Apparent equilibrium constant with the concentrations of morin, thorium, and total moles $\mathrm{Th}+$ morin all varying continuously .0.0.00000000000.40 


\section{A SPECTROPHOTOMETRIC STUDY OF THE THORIUM-MORIN \\ MIXED COLOR SYSTEM}

By Mary H. Fletcher and Robert G. Milkey

ABSTRACT

Thorium reacts with morin in solutions at a pH of 2.0 to yield a single complex that has a thorium:morin ratio of $1: 2$. The yellow complex has a maximum absorbance at $410 \mathrm{~m} \mu$ and is stable for at least 7 hours. The sensitivity of the reaction is such that as little as about 0.2 microgram of $\mathrm{ThO}_{2}$ in $50 \mathrm{ml}$ can be determined using a light path of $5 \mathrm{~cm}$. An average apparent equilibrium constant of approximately $1 \times 10^{6}$ was found for the reaction.

The effects of acidity, alcohol content, morin content, time, age of the morin reagent and temperature of the reaction have been studied as have the effect of some other ions. Zirconium and aluminum inter. fere seriously and must be absent. The interference from ferric iron is also serious but the effect may be appreciably decreased if hydroxylamine is added to the solution. Relatively large amounts of calcium and lanthanum may be present without causing interference, and these ions can be used as carriers in separations of thorium from other ions. Morin is a suitable reagent for the determination of thorium in pure solutions. If appropriate separations are found for the separation of thorium from other ions, the reaction will be useful for the determination of trace amounts of thorium in complex materials. The information presented in this paper is fundamental to any specific adaptation of the reaction to the analysis of complex materials. 


\section{INTRODUCTION}

In work conducted on behalf of the U.S. Atomic Energy Commission, the U.S. Geological Survey has been actively engaged in an investigation of the distribution of thorium in rocks and has found it necessary to analyze many samples for trace amounts of thorium. In this investigation the use of existing methods of analysis has demonstrated the need for a very sensitive and, if possible, selective reagent for the colorimetric and/or fluorimetric determination of thorium.

Because of this need, a search for a new reagent was started. To date, 93 organic compounds have been tested for their possible reaction with thorium. The conditions for the reactions were determined and their sensitivities compared. of the compounds tested--morin was the most sensitive.

Morin, 5,7,2', 4' flavanol, has the structure:<smiles>O=C1CCCC(O)C1C1OC2CC(O)CC(O)C2CC1O</smiles>

It is obtained as $\mathrm{C}_{15} \mathrm{H}_{10} \mathrm{O}_{7} \cdot 2 \mathrm{H}_{2} \mathrm{O}$ wi.th a molecular weight of 338.26 , or as $\mathrm{C}_{15} \mathrm{H}_{10} \mathrm{O}_{7}$ with a molecular weight of 302.23 , depending upon the method of preparation. It reacts with a number of metallic ions under various conditions of acidity to produce fluorescent and/or colored complexes $(1,4,5,11)$.

We are indebted to Dr. Charles $\mathrm{E}$. White of the Chemistry Department of the University of Maryland for supplying the morin used in this investigation.

The reaction between morin and thorium takes place under slightly acid conditions to give a yellow solution which exhibits a green fluorescence when exposed to ultraviolet light. Figure 1 shows a spectro- 
photometric curve for the yellow solution. (curve B) and one for a 'solution of pure morin (curve A). Although the pH of both solutions was 1.96 and each contained 600 micrograms of morin per 50 milliliters of solution, there was also the equivalent of $5.0 \mathrm{mg}$ of $\mathrm{ThO}_{2}$ in the solution used to obtain the data for curve B. The absorbance spectra in figure 1 represent a system highly favorable for quantitative analysis because the peak of the morin-plus-thorium curve occurs at a point where the absorbance for the morin is essentially zero, and the peaks of the two curves are well separated (350 m/ for morin and $410 \mathrm{~m} / \mathrm{f}$ for morin plus thorium).

Both the color and fluorescent systems were studied in order to evaluate the suitability of morin as a reagent for the quantitative determination of trace amounts of thorium. A discussion of the spectrophotometric study of the color system, and a method for the determination of thorium in pure solutions are presented here. This information will be fundamental to any specific adaptation of the reaction for the determination of thorium in rocks or other materials a

\section{EXPERTMENTAL DATA}

\section{Apparatus and reagents}

Beckman. DU quartz spectrophotometer

Beckman pH meter

Morin: $\mathrm{C}_{15} \mathrm{H}_{20} \mathrm{O}_{7} \cdot 2 \mathrm{H}_{2} \mathrm{O}$ (mol. wt. 338.26 ) of high purity was abtained from Dr. Theodor Schuchardt in Munchen, Germany. Solutions of morin of the strength desired were prepared by dissolving the solid material in 95 percent ethyl alcohol. The reagent adopted for use in analysis con- 


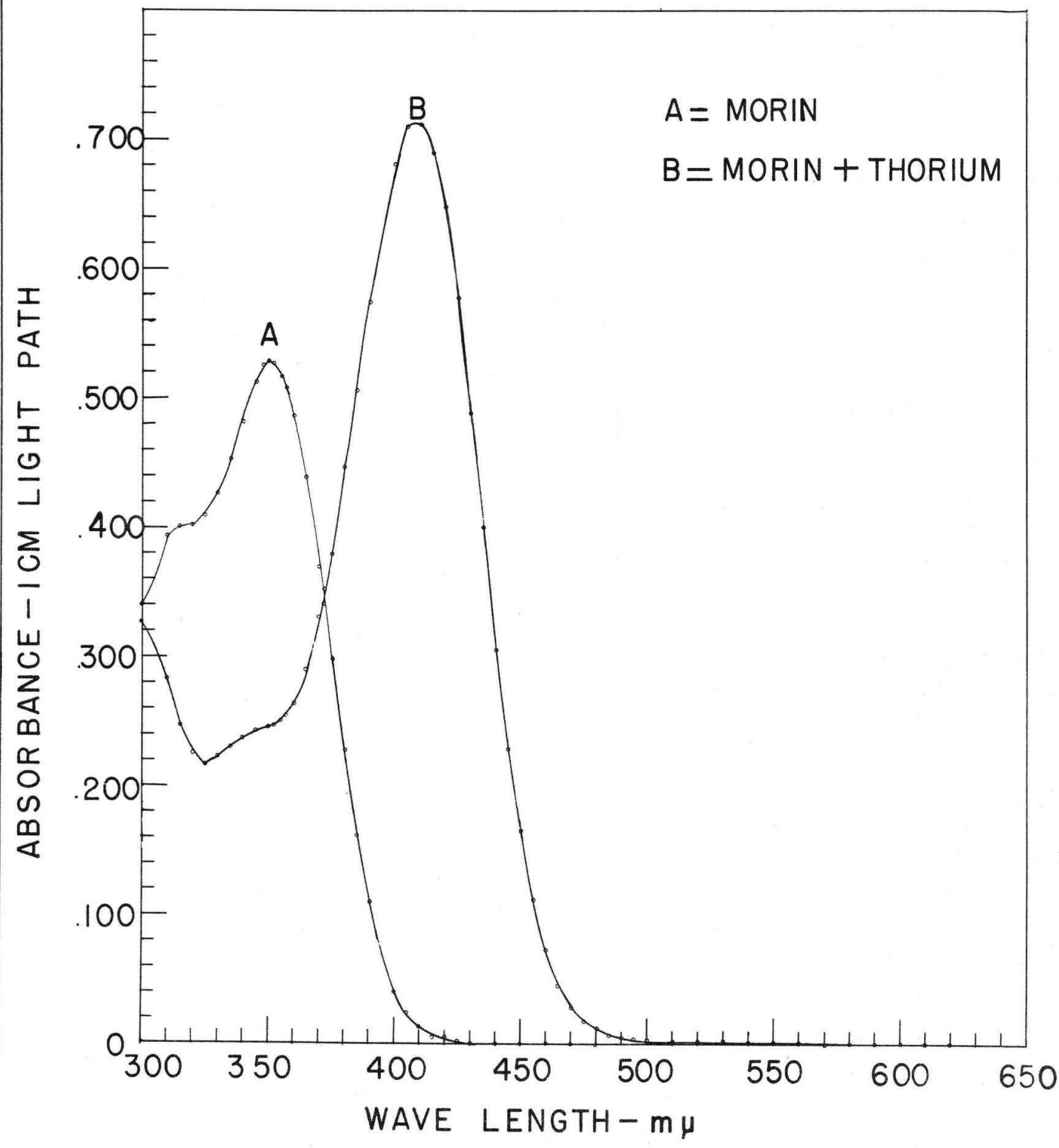

Figure 1.--Spectrophotometric curves of solution of thorium and morin (B) and pure morin (A). 
tained $1 \mathrm{mg}$ of morin per milliliter of alcohol.

Standard thorium solutions: Stock solutions of thorium chloride and. thorium nitrate were prepared by dissolving the respective salts (C.P. grade) in 3 percent hydrochloric or nitric acid. These solutions, which contained the equivalent of $100 \mathrm{mg}$ of $\mathrm{ThO}_{2}$ per milliliter, were standardized gravimetrically by precipitation of the hydroxide with ammonium hydroxide which had been freshly prepared from tank ammonia gas, after which the thorium hydroxide was ignited to $\mathrm{ThO}_{2}$ and weighed. Working solutions were prepared from the stock selutions by dilution with distilled water and, when necessary, by the addition of more acid. The acidity of all working solutions was adjusted to give a pH of 1.9 to 2.0; thorium solutions are stable at this pH (7)。 Hydroxylamine hydrochloride: C.P. grade, a 10 percent solution in distilled. water.

Materials tested as possible interferences: Stock solutions of the nitrates (C.P. grade) of a,luminum, calcium, iron, lanthanum, lead, uranium, and zirconium were prepared in nitric acid and diluted as required to give working solutions of the proper concentration and having a pH of $2.0 \%$. The working solutions were used immediately after dilution to avoid possible loss of solute from hydrolysis.

\section{Determination of conditions for maximum sensitivity and/or stability}

To establish the optimum conditions for the reaction between thorium and morin, it was necessary to determine the effects of the more important experimental variables. In studying these variables, a standardized order for the addition of reagents was adopted and the following general 
procedure was used for the preparation of all solutions:

The acid was added first, followed by thorium and enough water to make a total volume of about $20 \mathrm{ml}$. After the solution was mixed, $2 \mathrm{ml}$ of morin reagent was added, and the solution was mixed again. The volume was adjusted to exactly $50 \mathrm{ml}$, the solution was given a final mixing, and after ha.lf an hour, the absorbance was measured.

In each of the subsections which follow, one experimental variable is considered, its effect on the color evaluated, and the optimum condition for maximum sensitivity or stability selected.

Acidity --The most advantageous $\mathrm{pH}$ was determined from absorbance and $\mathrm{pH}$ measurements on two series of soiutions. In the first series, each solution contained $2.0 \mathrm{mg}$ of morin; and in the second series each of the solutions contained $2.0 \mathrm{mg}$ of morin and also the equivalent of 15 micrograms of $\mathrm{ThO}_{2}$ as the nitrate, thus simulating conditions for thorium analysis. The total alcohol content of each solution was $2 \mathrm{ml}$, but different amounts of nitric acid were added to the solutions so that each series covered the $\mathrm{pH}$ range of 1.4 to 3.0 . The absorbance at $410 \mathrm{~m} / \mathrm{h}$ and the corresponding $\mathrm{pH}$ values for the solutions of pure morin (1) and for those which contained both morin and thorium (2) are shown in figure 2. In the $\mathrm{pH}$ range of 1.4 to 2.0 , the absorbance for the morin solutions remained constant but the absorbance for the thorium solutions increased continuously. A pH of 1.9 to 2.0 was selected and maintained in a.I subsequent work because it was in the region of constant absorbance for the morin, and it was believed that less interference from other ions would result here than at a pH of 2.4 where the sensi- 


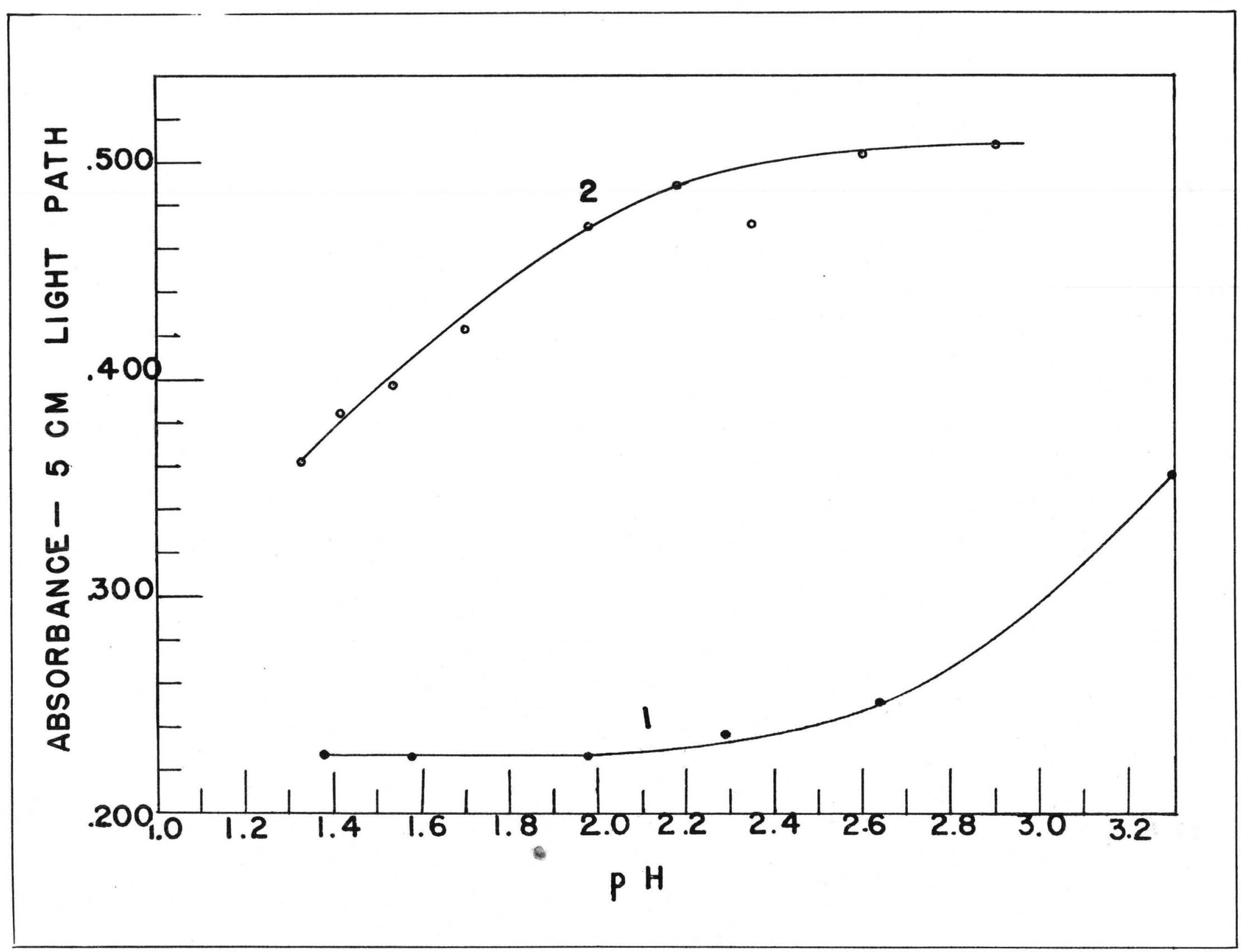
plus thorium (2). 
tivity was slightly higher and at a maximum.

Other experiments showed no essential difference in the reaction when either hydrochloric ox nitric acids were used. Although perchloric acid may be employed, sulfuric acid cannot be used because sulfates complex thorium to such an extent that no color develops.

Alcohol. - Two series of solutions were prepared with an alcohol content ranging from 2 to $16 \mathrm{ml}$ in each series. Each solution of the first series contained $2.0 \mathrm{mg}$ of morin only, and each solution of the second series contained 400 mierograms of morin completely coverted to the colored complex by an orerwhelming excess of thorium (50 $\mathrm{mg}$ ThO 2 )。

The curves in figure 3 show the relationship between the absorbance at $410 \mathrm{~m} / \mathrm{a}$ and the alcohol content for these solutions. When the alcohol is increased from 2 to $16 \mathrm{ml}$, the absorbance for pure morin increased. 37 percent (1), and the absorbance for the complex decreased 2 percent (2). The difference in absorbance between the two curves at any point indicates the sensitivity of the measurement for a given alcohol contento The over all seasitivity of the measurements, when the values are on the basis of equal light paths, decreased about 6 percent when the alcohol was increased from 2 to $16 \mathrm{ml}$. Inasmuch as the smaller amount of alcohol Is optimum for maximum sensitivity, a total alcohol content of $2 \mathrm{ml}$ was adopted in the standard procedure.

Time of standing,--Having established the acidity and alcohol content for the standard procedure, the stability of the color was determined by periodic absorbance readings on three solutions. The first solution contained $2.0 \mathrm{mg}$ of morin; the second contained the equivalent of 15 micrograms of $\mathrm{ThO}_{2}$ completely converted to the colored complex by an excess of morin ( $2.0 \mathrm{mg}$ ); and the third contained 400 micrograms of morin 


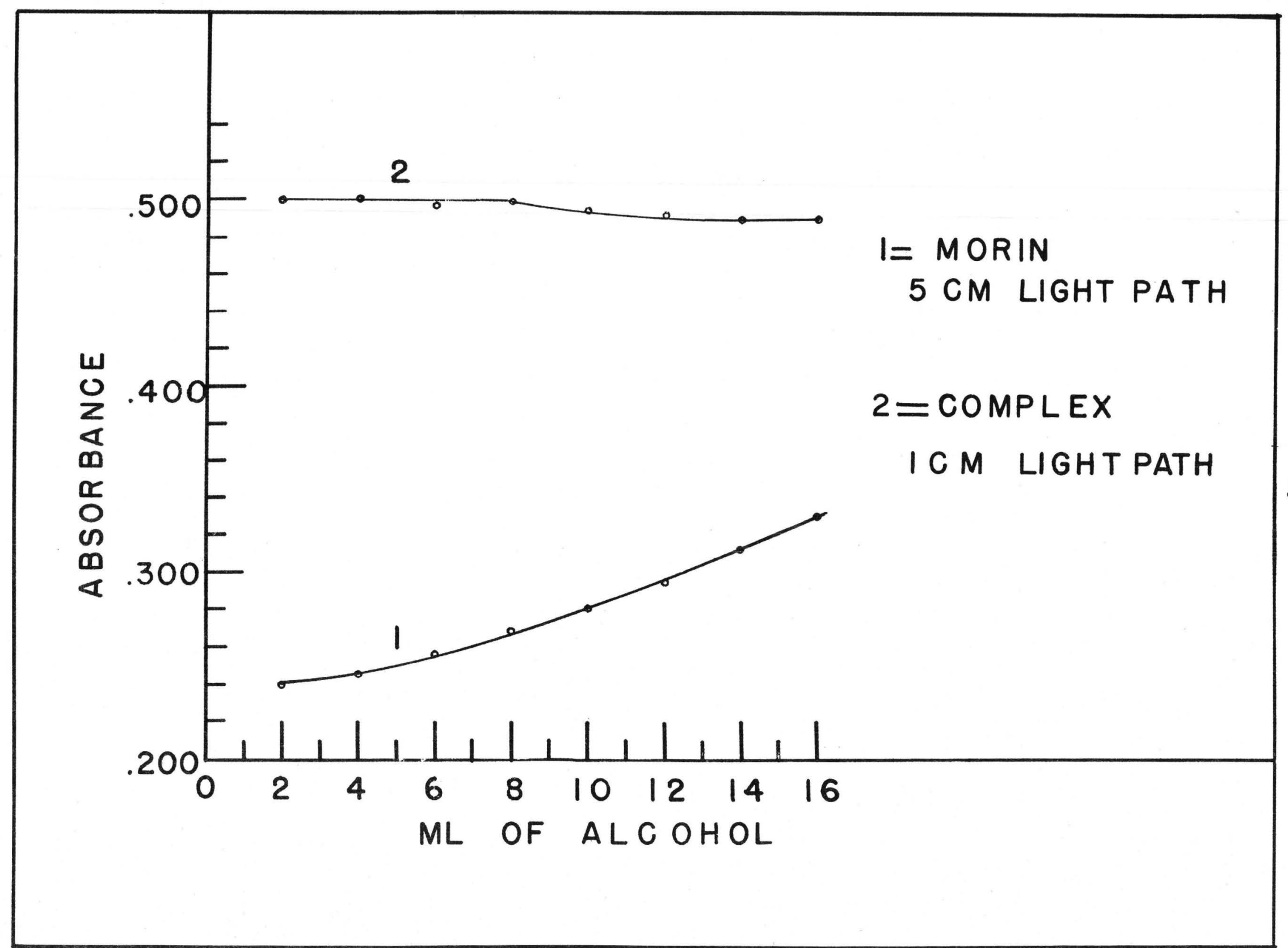
Figure 3.--Effect of alcohol concentration on absorbance at $410 \mathrm{~m} / 4$ for pure morin (1)
and morin plus thorium (2). 
completely converted to the colored complex by an excess of thorium (50 $\mathrm{mg} \mathrm{ThO}_{2}$ ).

The absorbance at $410 \mathrm{~m} /$ for each solution, plotted as a function of the time elapsed between preparation of the solution and measurement of its absorbance, is shown in figure 4 where the curves indicate practically constant absorbance for at least 7 hours. In solution one, where the change was greatest, the total change in absorbance during 7 hours was about 2.5 percent which is within the aceepted experimental error for colorimetric work. After a period of 24 hours, the maximum change in absorbance occurred in solution 3. The drop here was about 4 percent. It may be concluded, therefore, that the color of the solutions is quite stable. In the standard procedure, one-half hour was allowed for the color to reach equilibrium before the absorbance was measured.

Morin concentration. "Wwo series of solutions were prepared; in the first series, each of 23 solutions contained 15 micrograms of ThO and an amount of morix wich ranged from 0 to 4000 micrograms; in the second. series, each of 9 solutions contained morin alone and in an amount which ranged from 0 to 4000 micrograms. A curve was drawn for each series of solutions showing the absorbance at $410 \mathrm{~m} / \mathrm{f}$ as a function of the original morin content. Subtraction of the ordinates of the curve for the morin blanks from the ordinates of the curye for the solutions which contained thorium as we11 as morin gave the absorbance due to the complex. These values were used to prepare the curve in figure 5 , which, in effect, shows the amount of complex formed as a function of the original morin content of the solutions and indicates essentially complete reaction when 2500 micrograms or more of morin are present. 


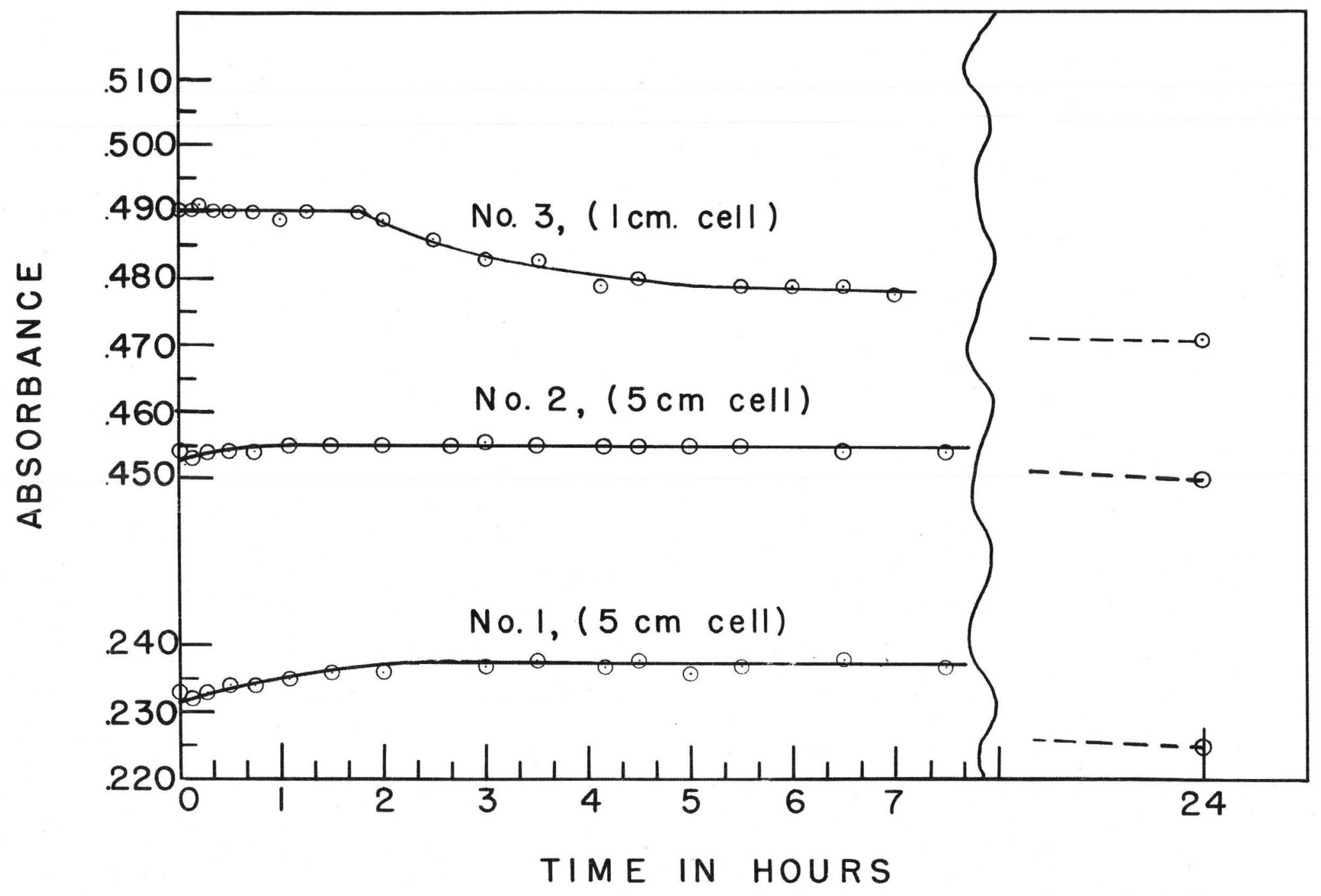




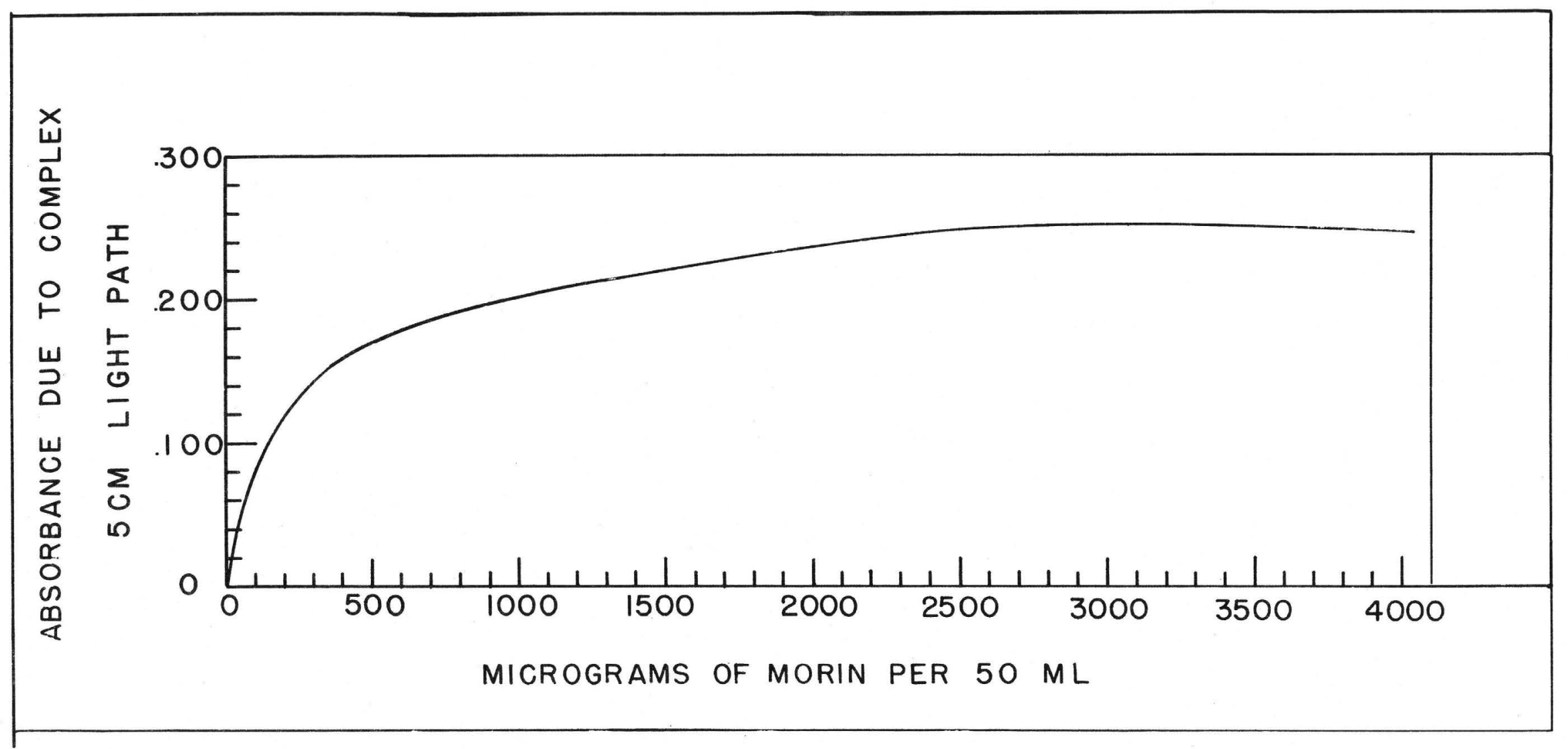

Figure 5.--Effect of morin concentration. 
In other similar experiments, a precipitate formed in solutions containing 80 micrograms of $\mathrm{ThO}_{2}$ when the morin content was as low as 2000 micrograms; precipitation also occurred when the $\mathrm{ThO}_{2}$ was reduced to 50 micrograms if the morin content was increased to 2800 micrograms or more. Accordingly, 2000 micrograms of morin was selected as the best compromise, because this amount gives practically complete reaction, and also insures against precipitation for as much as 60 micrograms of $\mathrm{ThO}_{2}$.

Age of morin reagent solution. - -Three solutions of morin reagent which had been standing in the laboratory for varying periods of time were tested to determine if the reagent deteriorates with age. Each of the three reagents was used to prepare a standard blank containing $2 \mathrm{mg}$ of morin, and each was also used to prepare a solution of the complex using 400 micrograms of morin plus $50 \mathrm{mg}$ of ThO at $4.10 \mathrm{~m} /$. for the solutions of blanks and complex as well as the age of the morin reagent are presented in table I. It will be seen that solutions of morin in ethyl alcohol are essentially stable for at least 4 months under usual laboratory conditions and that use of morin solutions several months old will introduce no gross errors.

Temperature.-The effect of temperature on absorbance was checked in an approximate manner, as follows: $500 \mathrm{ml}$ of a solution which contained the equivalent of 15 micrograms of $\mathrm{ThO}_{2}$ and $2.0 \mathrm{mg}$ of morin per 50 ml was prepared and divided into two parts。 One portion was warmed in hot water to about $40 \mathrm{C}$ and the other portion cooled in ice water to about $5 \mathrm{C}$. The temperature of these two solutions was then allowed to come to equilibrium at room temperature. During the period that the temperatures were approaching equilibrium, portions of each solution were removed periodically, the absorbance was measured, and 
Table 1.--Effect of age of morin reagent on absorbance measurements.

\begin{tabular}{|c|c|c|}
\hline \multirow[b]{2}{*}{$\begin{array}{c}\text { Age of morin } \\
\text { solution }\end{array}$} & \multicolumn{2}{|c|}{ Absorbance } \\
\hline & $\begin{array}{c}\text { Morin } \\
2.0 \mathrm{mg} / 50 \mathrm{ml} \\
\text { solution } \\
(5-\mathrm{cm} \text { cell) }\end{array}$ & $\begin{array}{l}\text { Complex } \\
400 \text { micrograms morin } \\
\text { plus } 50 \mathrm{mg} \mathrm{ThO}_{2} / 50 \mathrm{ml} \\
\text { solution } \\
\text { (I-cm cell) }\end{array}$ \\
\hline$I$ day & 0.235 & $\infty$ \\
\hline 3 months & .235 & $\infty$ \\
\hline 4 months & .242 & $-\infty$ \\
\hline 3 weeks & هo & 0.492 \\
\hline $31 / 2$ months & $-\infty$ & .481 \\
\hline $41 / 2$ months & $-\infty$ & .481 \\
\hline
\end{tabular}

the temperature of the solution recorded. The values for the absorbance and the corresponding temperatures are shown in figure 6 . It will be noted that changes in temperature affect the absorbance readings somewhat. The effect however is small for such variations as generally occur in room temperature over a period of a few hours. Nevertheless, care must be used in comparing absorbances obtained on different days or in different seasons of the year if there is a possibility that the measurements were made at greatly different temperatures.

\section{NATURE OF THE REACTION}

Selection of the conditions for the color development was followed by an investigation of the reaction to determine whether it is stoichiometric and to ascertain the number and composition of the complexes which might be formed. Sixteen solutions were prepared; each contained 


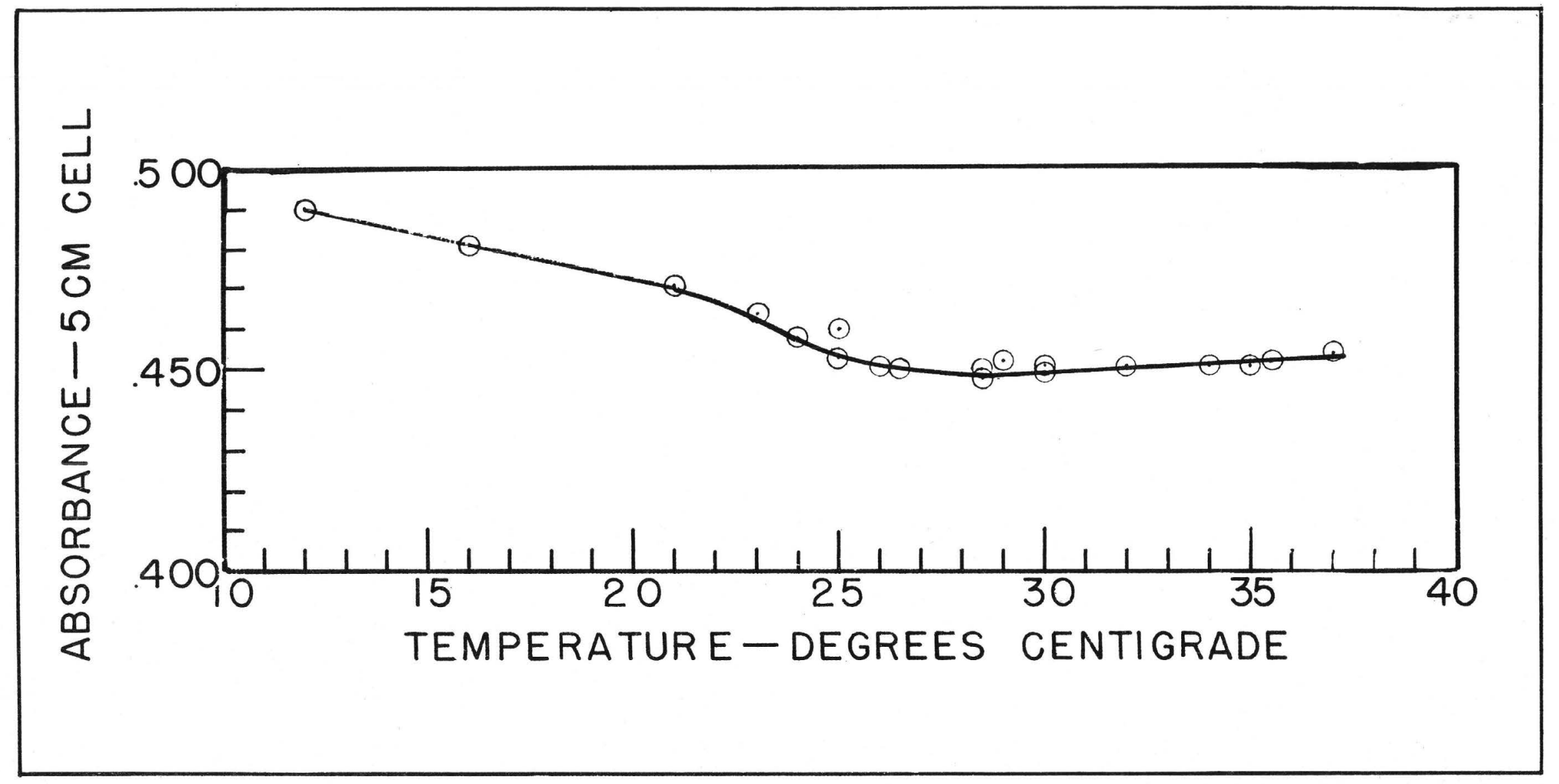

Figure 6.--Effect of temperature on absorbance. 
600 micrograms of morin and an amount of thorium nitrate which ranged. from 0 to $50.3 \mathrm{mg}$ of equivalent ThO 2 . The absorbances of these solutions were measured at different wavelengths and spectrophotometric curves were prepared. The resulting family of curves are shown in figure 7 .

The occurrence of an isobestic point (2) which is shown at a wavelength of approximately $372 \mathrm{~m} / \mathrm{s}$, in figure 7 , indicates that only one complex is formed; such a family of curves with an isobestic point is very strong evidence that only two light-absorbing components, in this case morin and complex, are present and in equilibrium $(9,10)$.

The changes which occur in the shape of the curves as the composition of the solutions vary again indicate that only one complex is formed. Curve I, (fig.7) is the curve for pure morin, and the other curves, in numerical order, are for solutions containing larger and. larger amounts of thorium. As the amount of thorium increases, more and. more complex was formed in the reaction represented by the equation.

$$
\mathrm{x} \cdot \mathrm{Th}+\mathrm{y}+\mathrm{M} \cdot \mathrm{H} \rightleftarrows \mathrm{Th}_{\mathrm{x}} \mathrm{M}_{\mathrm{y}}+\mathrm{yH}^{+} \text {(where } \mathrm{M}_{0} \mathrm{H}=\operatorname{mor} i n \text { ) }
$$

Thus, with each additional increment of thorium, there was a corresponding decrease in the amount of free morin, which was revealed by the diminishing absorbance of the peak at $350 \mathrm{~m} /$. Simultaneous with the diminution of this peak was the development of another peak at $410 \mathrm{~m} /$. The second peak is characteristic of the complex and the talue of its absorbance grew larger as the amount of complex increased. When the thorium content reached about $7 \mathrm{mg}$ of equivalent $\mathrm{ThO}_{2}$, further increases up to $50.3 \mathrm{mg}$ of $\mathrm{ThO}_{2}$ resulted in less than a two percent increase in the absorbance at $410 \mathrm{~m} / \mu$.

This last point is demonstrated more clearly in figure 8 where the absorbance readings at $410 \mathrm{~m} / 4$ were plotted as a function of the thorium. 


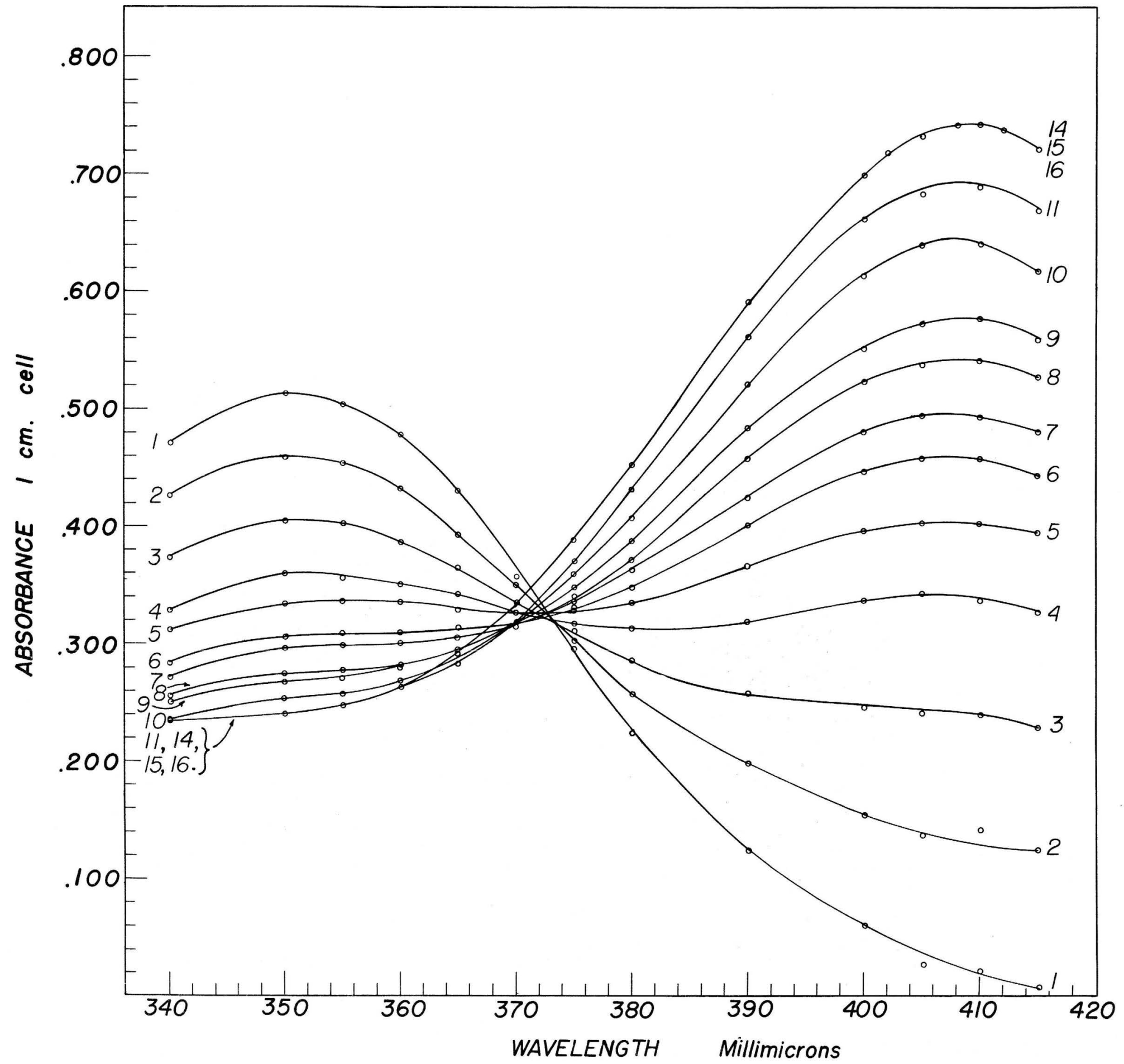

Figure 7.--Spectrophotometric curves showing isobestic point. 


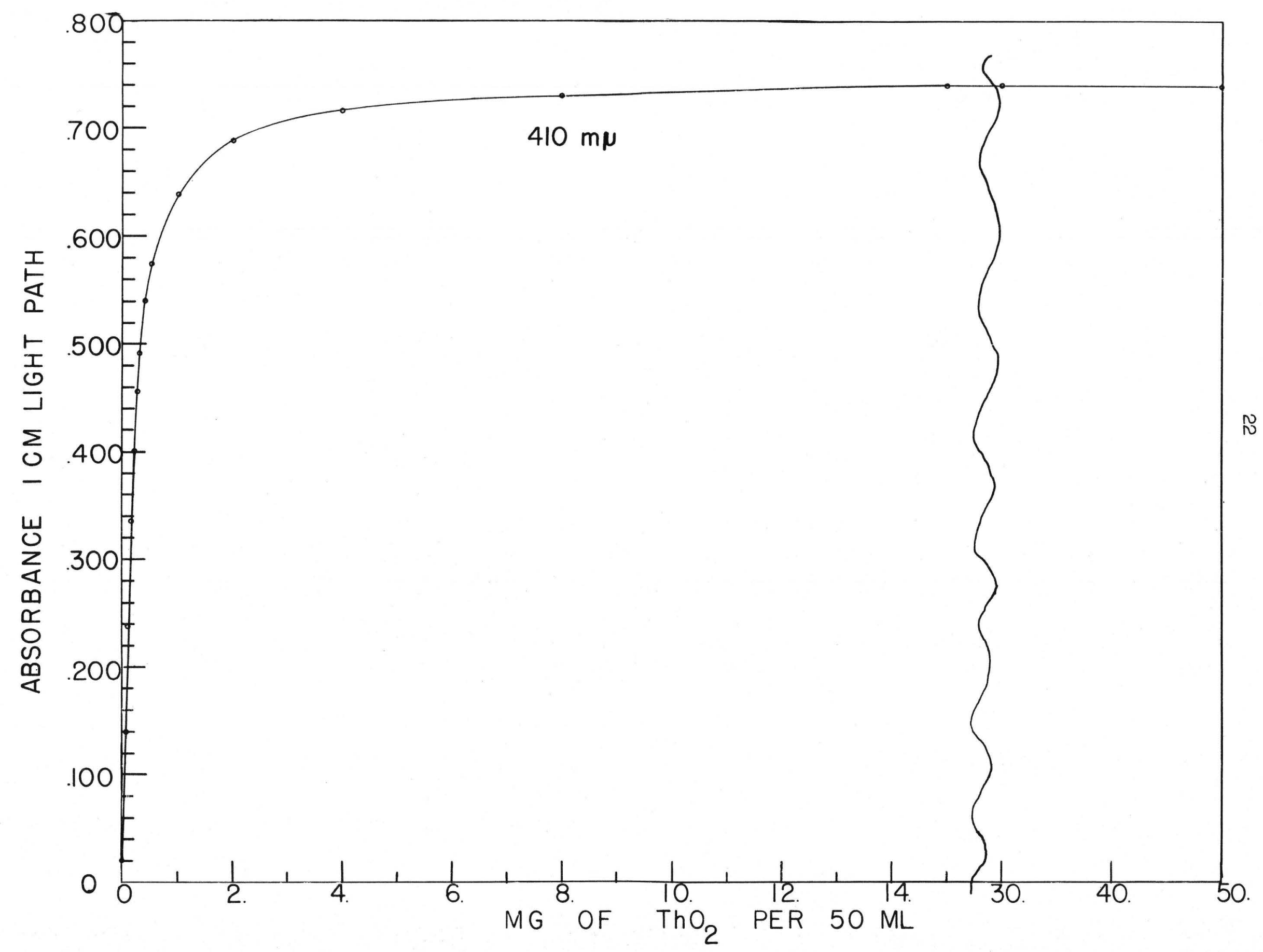

Figure 8.--Absorbance at $410 \mathrm{~m} \mu$ as a function of thorium concentration. 
concentration. In figure 7, a single curve resulted from solutions 14, 15, and 16 and this curve represents the absorbance spectrum for the pure complex.

\section{DETERMINATION OF THE COMPOSITION OF THE COMPLEX}

After establishing that only one complex is formed, the method of continuous variations $(6,12)$ was used to determine the composition of the complex. Twenty-eight solutions were prepared, each contained. thorium and morin in different proportions; but in each solution, the combined concentration of thorium and morin was always $3 \times 10^{-6}$ moles. The absorbances of these solutions were measured at three different wavelengths; and for each measurement, a value $\Psi$ was calculated which was equivalent to the difference between the measured absorbance and the absorbance the solution would have had if there had been no reaction. These values for $Y_{2}$ plotted as a function of the composition of the solutions are given in figure $9:$ a separate curve was prepared for each of the three wavelengths. Job, and Vosburg and Cooper $(6,12)$ have shown that the value of $\Psi$ at each wavelength is at a maximum when the greatest amount of complex is formed. This occurs when the ratio of the molar amounts of the two reactants is exactly equal to their combining ratios.

A.1 of the curyes in figure 9 reach a peak at the same abscissa. At this point the moles of morin are essentia.11y twice as great as the moles af thorium. The ratio of thorium to morin in the complex is therefore one to two, and an abbreviated formula for the complex may be 
written as ThM2. A possible structure for this complex is

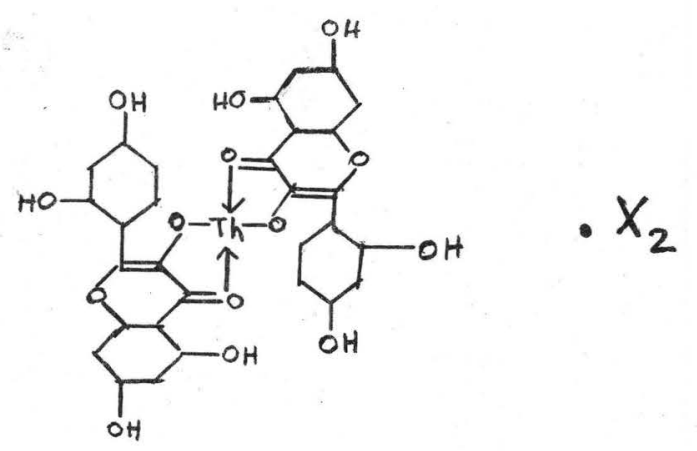

where $X$ is a univalent negative ion such as $\mathrm{Cl}^{-}$or $\mathrm{NO}_{3}$.

In addition to giving the mole ratio of thorium to morin in the complex, the curves in figure 9 a.lso substantiate the earlier conclusion that only one complex is formed. The curves for three different wavelengths a.1 show peaks at the same molar ratio; moreover, all of the curves are smooth and contiouous, no secondary peaks appear, and the curves are concave with respect to the abscissa. These character istics a.1 indicate the formation of a single complex (12).

The conclusion that the mole ratio of the thorium to morin in the complex is one to two substantiated according to the slope ratio method (3) by absorbance measurements at $410 \mathrm{~m} / \mathrm{h}$ on two series of solutions. The first series contained amounts of morin which ranged from 0 to 1000 micrograms and an excess of thorium (50 $\mathrm{mg}$ Tho 2 ) which insured complete reaction of the morin to form complex. The second series contained amounts of ThO $\mathrm{O}_{2}$ which ranged from 0 to 30 micrograms and an excess of morin ( $2.0 \mathrm{mg})$ which was sufficient to insure essential1y complete reaction for the small amounts of thorium employed.

In figure 10 the absorbance and corresponding moles of morin per liter for the first series of solutions are shawn in curve $I_{\text {, whereas }}$ the absorbance and corresponding moles of tborium per liter for the 


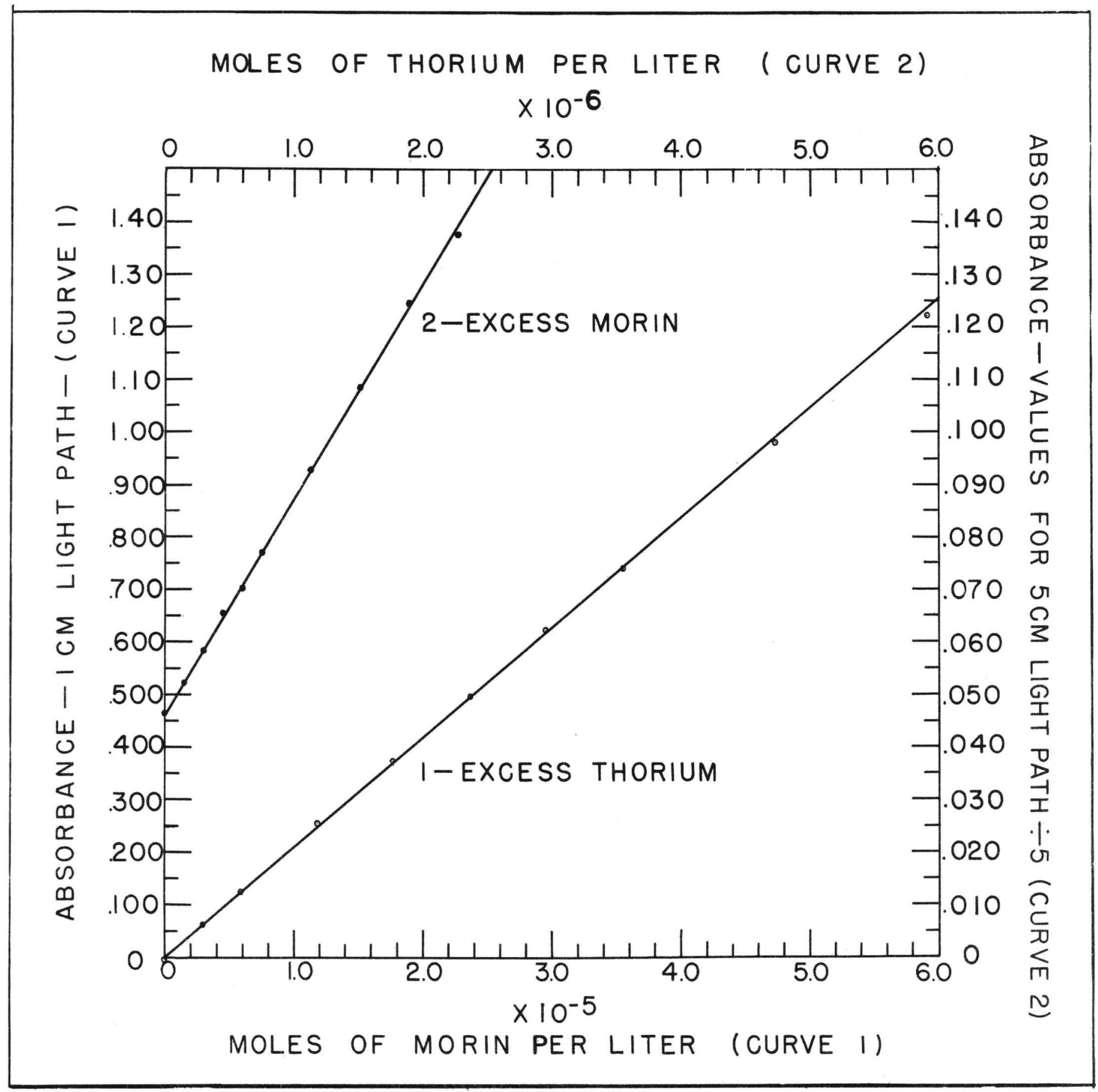

Figure 10.--Determination of composition of complex by slope-ratio method. 
second series are shown in curve 2 .

The slope of curve 1 is $2.092 \times 10^{4}$ and represents the rate of change in the absorbance of the complex per mole of morin complexed. The slope of curve 2 is $4.105 \times 10^{4}$ and represents the rate of change in the absorbance of the complex per mole of thorium complexed. But absorbance is proportional to the moles of complex formed, therefore

$$
\begin{gathered}
\frac{\text { Slope } 1}{\text { Slope } 2}=\frac{2.092 \times 10^{4}}{4.105 \times 10^{4}}=\frac{1}{1.96}=\frac{\Delta \text { Absorbance } / \text { mole of morin }}{\Delta \text { Absorbance } / \text { mole of thorium }} \\
\text { and } \frac{\Delta \text { moles of complex } / \text { mole of morin }}{\Delta \text { moles of complex } / \text { mole of thorium }}=\frac{1}{2}
\end{gathered}
$$

thus substantiating the earlier conclusion.

The linear relationships shown in figure 10 indicate that light absorption by the complex follows Beer's law:

$$
\text { where } \quad \begin{aligned}
& P_{0}=P_{0} 10^{-a b c} \text { transmitted radiant power } \\
& P_{0}=\text { incident radiant power } \\
& a=\text { absorptivity or specific absorbance } \\
& \epsilon=\text { absorptivity when } c \text { is expressed in moles } \\
& \text { per liter } \\
& b=\text { internal cell length } \\
& c=\text { concentration of complex }
\end{aligned}
$$

Thus, the absorbance, $A=a b c$ or $\epsilon_{b c}$

and the absorptivity, $a=A / b c$

and $\epsilon=\mathrm{A} / \mathrm{bc}$ when $c$ is expressed in moles per liter

The molar absorptivity for the complex, $\epsilon_{\mathrm{ThM}_{2}}$, may be determined from curve I (fig. 10) which gives the change in absorbance of the complex per mole of morin complexed. However, as each mole of complex contains two moles of morin, twice the slope of curve 1 gives the change in the 
absorbance of the complex per mole of complex, which is $\epsilon_{\mathrm{ThM}_{2}}$.

Equation (3a) was used to determine the absorptivity for morin using the data from the curve in figure 11 which shows the absorbance values for a series of pure morin solutions.

The absorptivity values at $410 \mathrm{~m} / \mathrm{h}$ are as follows:

For the complex.

$\epsilon_{\mathrm{ThM}_{2}}=4.184 \times 10^{4}$ liters/mole $\times \mathrm{cm}$

$a_{\mathrm{ThM}_{2}}=5.013 \times 10^{-2} \mathrm{~cm}^{2} /$ microgram
For pure morin

$$
\epsilon_{\mathrm{M}}=3.767 \times 10^{2} \times 1 \text { iter } / \mathrm{mole} \times \mathrm{cm}
$$

$a_{M}=1.120 \times 10^{-3} \mathrm{~cm}^{2} /$ microgram

DETERMINATION OF COMPONENIS OF ANY SOLUTION

AND CALCULATION OF EQUILIBRIUM CONSTANT

In any solution composed of several components which absorb light, the total absorbance of the solution is equal to the sum of the individual absorbances. In the morin-thorium system there are only two components which absorb light, morin and the complex, ThMz.

If $\mathrm{X}=$ moles of complex per liter present

$$
\begin{aligned}
& \mathrm{M}=\text { total moles of morin per liter added } \\
& \mathrm{Y}=\text { moles of uncombined morin per liter }
\end{aligned}
$$

Then the absorbance, A, of any given solution can be expressed as

$$
A=\epsilon_{M^{Y b}}+\epsilon_{\mathrm{ThM}_{2} \mathrm{Xb}}
$$

The morin originally added is distributed between the combined and uncombined states, and each mole of complex contains two moles of combined morin.

Thus, the total morin, $M=Y+2 X$

$$
\text { and } \mathrm{Y}_{0}=\mathrm{M}_{r}-2 \mathrm{X}
$$




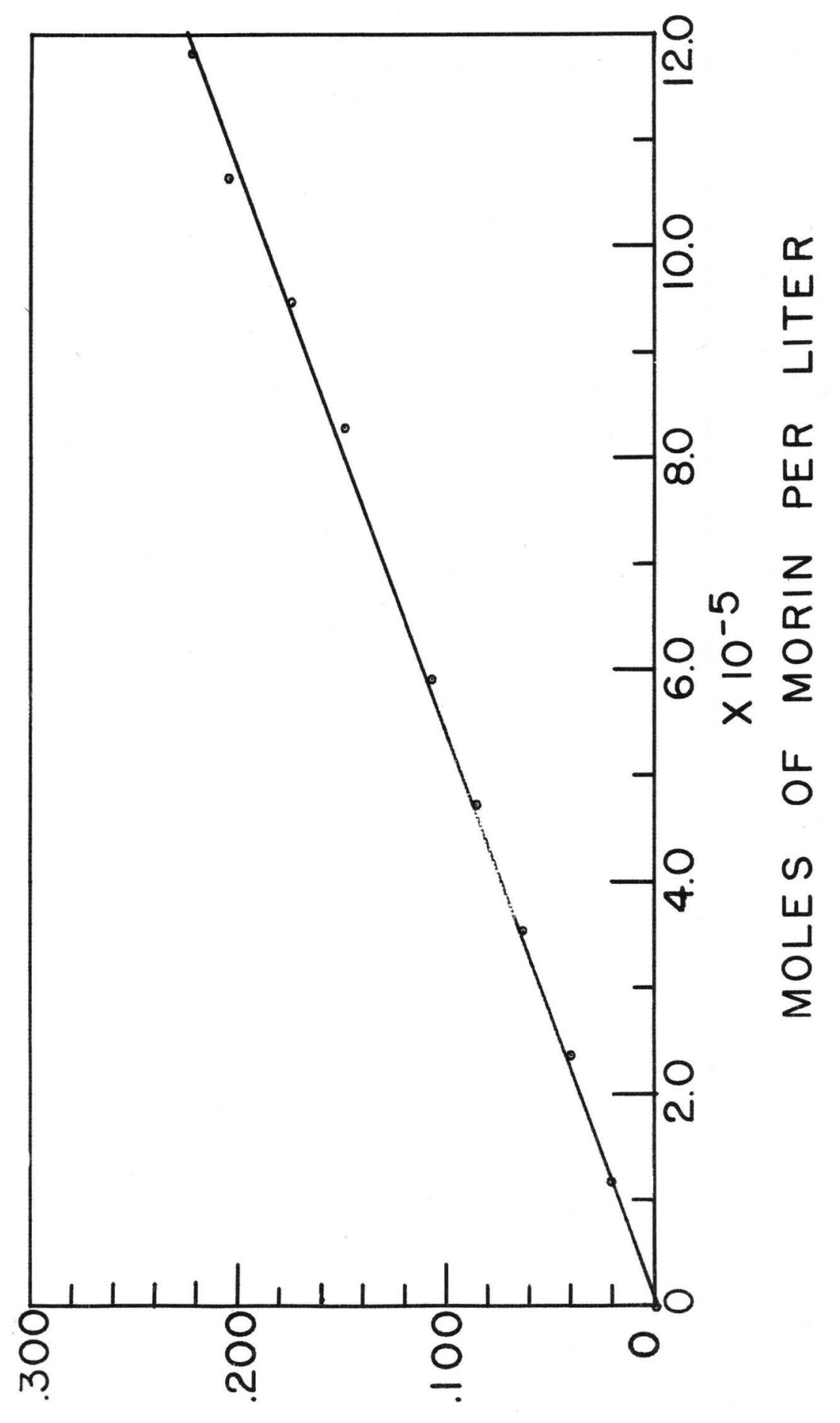

वं

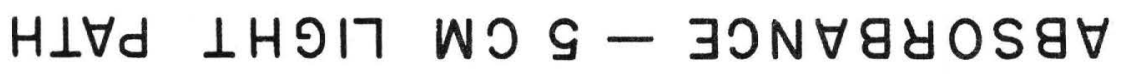


Substituting in equation (4)

$$
\frac{\mathrm{A}}{\bar{b}}=\epsilon_{\mathrm{M}}(\mathrm{M}-2 \mathrm{X})+\epsilon_{\mathrm{ThM}_{2}} \mathrm{X}
$$

and

$$
X=\frac{A-\epsilon_{M} \mathrm{Mb}}{\mathrm{b}\left(\epsilon_{\mathrm{ThM}_{2}}-2 \epsilon_{\mathrm{M}}\right)}
$$

Using equation (8), the moles of complex per liter formed in any solution can be calculated, as can the amounts of uncombined morin and thorium. These values may then be used to calculate the apparent equilibrium constant for the reaction

$$
\mathrm{Th}^{+4}+2 \mathrm{M} \mathrm{H} \rightleftarrows \mathrm{ThM}_{2}^{++}+2 \mathrm{H}^{+}
$$

according to the equation

$$
\mathrm{K}_{\text {equil. }}=\frac{\left(\mathrm{ThM}_{2}^{++}\right)\left(\mathrm{H}^{+}\right)^{2}}{\left(\mathrm{Th}^{+4}\right)(\mathrm{MH})^{2}}
$$

In this study, the concentration of the hydrogen ion, (H), was constant at $\left(10^{-2}\right)$ because a pH of 2.0 was maintained in a.1工 solutions.

The apparent equilibxium constants calculated from the data for four sets of solutions are given in the appendix (tables $4,5,6$, and 7); the original concentrations of the morin and thorium and the absorbance values for each solution are included in these tables. Some of these data have already been presented in other ways. For example, the absorbance values and the thorium concentrations in table 4 were used previously to prepare figures 7 and 8 , and the information in table 6 was used to prepare figure 9. Table 5 pertains to solutions which contained 50.3 micrograms of $\mathrm{ThO}_{2}$ and amounts of morin which varied from 0 to 1000 micrograms per $50 \mathrm{ml}$, and table 7 pertains to solutions in which the morin, thorium, and total molar content all varied. The mean apparent $K_{\text {equil. }}$ derived from these four sets of solutions was approximately $1 \times 10^{6}$ 。 
EFFECT OF OTHER IONS

Zirconium, aluminum, ferrie and ferrous iron lons, which were considered as possible serious interferences because of their tendency to form complexes with moring calcium and lanthanum, which might be useful as carriers in separations of thorium from other ions; and also uranium and lead were tested under the standard conditions for their reaction with morin. The sensitivity of the reaction for each of these substances with morin is given in table 2 .

Table 2.-weight of warious substances in $50 \mathrm{ml}$ of solution which are equivalent to an absorbance difference of 0.010 at $4.10 \mathrm{~m} / \mathrm{h}$ when measurements are made in a $5 \infty \mathrm{cm}$ cell.

\begin{tabular}{cc}
\hline Substance & $\begin{array}{c}\text { Mierograms equivalent to } \\
0.01 \text { absorbance }\end{array}$ \\
\hline $\mathrm{ThO}_{2}$ & 0.69 \\
$\mathrm{ZrO}_{2}$ & 0.79 \\
$\mathrm{Fe}_{2} \mathrm{O}_{3}$ & 1.3 \\
$\mathrm{Al}_{2} \mathrm{O}_{3}$ & 15.6 \\
$\mathrm{Fe}_{2} \mathrm{O}_{3}($ in presence of & 28.6 \\
$\mathrm{U}$ & 89. \\
$\mathrm{~Pb}$ & 500. \\
$\mathrm{La}$ & 700. \\
$\mathrm{CaO}$ & $37 \times 10^{3}$
\end{tabular}

The maximum absolute amounts of the interfering ions which may be present in the final solution are determined by the amount of thorium 
present. Thus, if an accuracy of 90 percent or better is required in the determination, the ratios of the interference to ThO $0_{2}$ must be less than the values in table 3 .

Table 3, weight ratio of interfering substance to $\mathrm{ThO}_{2}$ for 90 percent accuracy in determination of $\mathrm{ThO}_{2}$ 。

Substance/ $\mathrm{ThO}_{2}$

Ratio

$\begin{array}{lc}\mathrm{ZrO}_{2} / \mathrm{ThO}_{2} & 0.1 / 1 \\ \mathrm{Al}_{2} \mathrm{O}_{3} / \mathrm{ThO}_{2} & 2 / 1 \\ \mathrm{Fe}_{2} \mathrm{O}_{3} / \mathrm{ThO}_{2} & 4 / 1 \\ \mathrm{La}_{2} \mathrm{O}_{3} / \mathrm{ThO}_{2} & 102 / 1 \\ \mathrm{CaO} / \mathrm{ThO}_{2} & 5360 / 1\end{array}$

*In presence of hydroxylamine

Zirconium and aluminum are serious interferences and must be virtum ally absent when trace amounts of thorium are determined. Both of these ions can be separated from thorium by making repeated precipitations of the thorium with hydrofluoric acid with use of a carrier. Interference from ferric iron is serious also, but the effect is appreciably decreased if the iron is reduced. with hydroxylamine. As much as $400 \mathrm{mg}$ of hydroxylamine may be added to the solutions with little or no effect on the reaction between thorium and morin; in fact, hydroxylamine is now added as a standard practice to all solutions. The interference from relatively large amounts of calcium and lanthanum is negligible and these lons can, therefore, be used as carriers in separations of thorium from other ions. Because the separations necessary to remove zirconium from thorium would 
separate most of the other cations as well, no further studies were made with other ions.

Having established the effect of various factors on the color of the complex formed in the reaction between thorium and morin, the standard procedure finally adopted for the preparation of solutions for the detero mination of thorium may now be given in detail.

DETAILED PROCEDURE FOR THE DEIERMINATION OF THORIUM IN PURE SOLUTIONS

The colored solutions are genera.1.y prepared in 50-ml glass-stoppered graduates or volumetric flasks。

1. Add $1.0 \mathrm{ml}$ of $0.63 \mathrm{~N} \mathrm{HCl}$ or $\mathrm{HNO}_{3}$.

2. Add the solution containing not more than 60 mierograms of $\mathrm{ThO}_{2}$. and free from other ions.

(The pH of thorium solution should be previously adjusted to 2.0)

3. Add $4 \mathrm{ml}$ of 10 percent solution of hydroxylamine hydrochloride.

4. Adjust rolume to about $20 \mathrm{ml}$ with water, and mix.

5. Add $2.0 \mathrm{ml}$ of morin reagent $(0.10$ percent in ethyl alcohol).

6. Mix。

7. Adjust volume to exactly $50 \mathrm{ml}$ with distilled water.

8. Stopper and mix thoroughly.

9. After half an hour measure absorbance at $410 \mathrm{~m} / \mathrm{0}$

A standard curve derived from known amounts of $\mathrm{ThO}_{2}$ in solutions prepared according to the above procedure is given in figure 12. The sensim tivity of the reaction, as obtained from this curve using Sandell's criterion (8) of an absorbance difference of 0.001 as the limit of detection, is 0.0070 microgram of $\mathrm{ThO}_{2}$ per $\mathrm{cm}^{2}$. This means that 0.0014 mierogram 


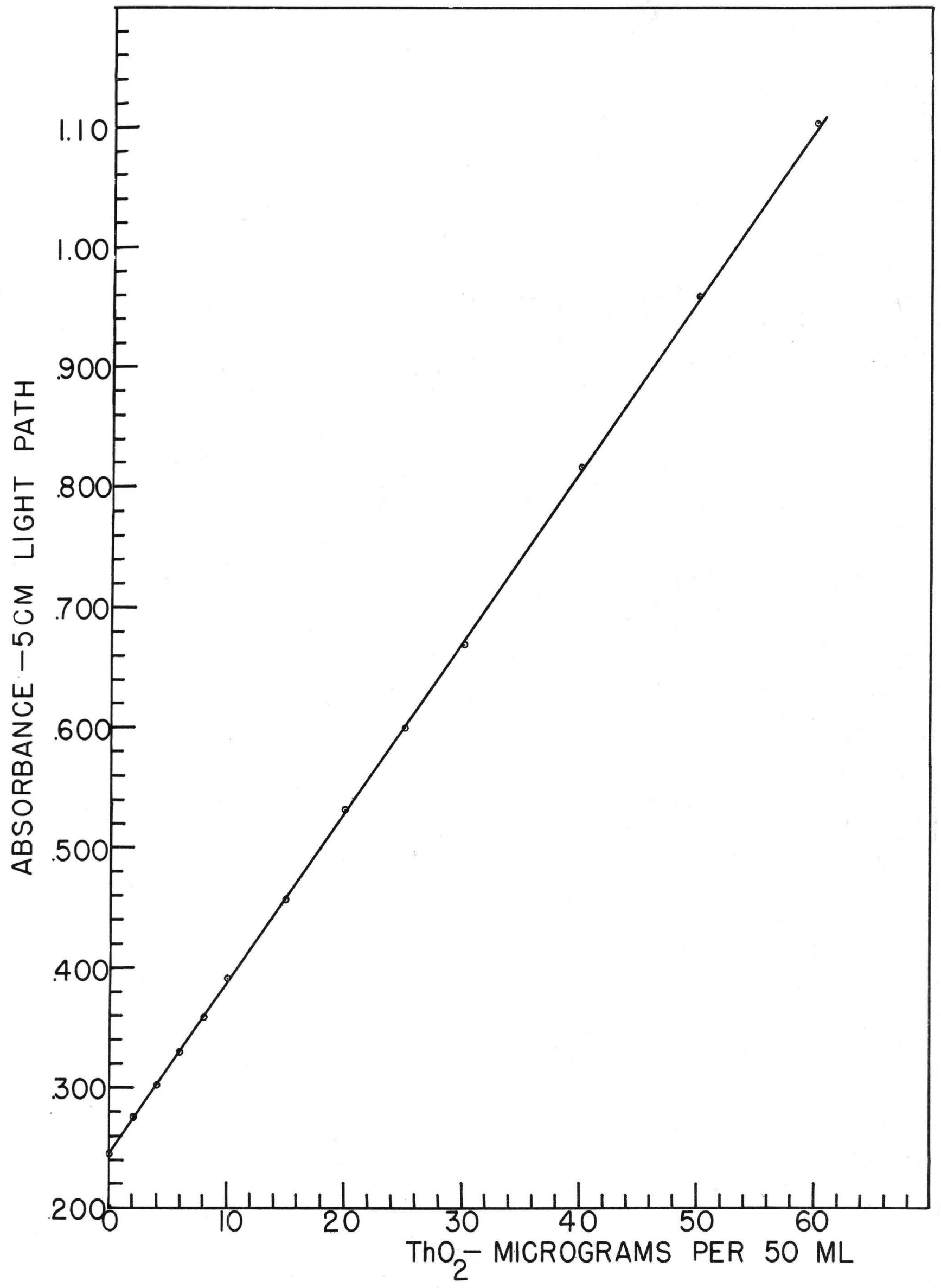

Figure 12.--Standard curve. 
of $\mathrm{ThO}_{2}$ per $\mathrm{ml}$ can be detected using a 5-cm light path.

\section{CONCLUSIONS}

It may be concluded that morin is a suitable reagent for the determination of trace amounts of thorium in pure solutions. As little as about 0.2 microgram of $\mathrm{ThO}_{2}$ in $50 \mathrm{ml}$ can be determined. However, the reaction can be adapted to the analysis of complex materials only after suitable separations of thorium from other ions have been made.

\section{REFERENCES}

(1) Bishop, Edmund (1950) The influence of anions on the morin test for aluminum, gallium, beryllium, and zine, and the identification of certain anions: Anal. chim. Acta, v. 4, p. 6-11.

(2) Brode, Wallace R. (1943) Chemical spectroscopy, 2d ed., New York, John Wiley and Sons, p. 248-250.

(3) Harvey, Aubrey, E。, Jro, and Manning, Delmer L。 (1950) Spectro photometric methods of establishing empirical formulas of colored complexes in solution: Am。 Chem. Soc. Jour., v. 72, p. 4488-4493.

(4) Goto, Hidehiro (2938) Fluorescent analysis VI. Fluorescent detection: Chem. Soc. Japan Jour。, vo.59, p。 625-633.

(5) Gôto, Hidehiro (1940-41) Fluorescence analysis, Part VI. Fluorescence detection: Tohoku Imp. Univ. Sci. Repts。, lst ser., p. 287-303.

(6) Job, P. (1928) Recherches sur la formation de complexes minéraux en. solution, et sur leur stabilite: Annales chim., (10) v. 9, p. 113-203.

(7) Milkey, Robert G. (1954) Stability of dilute solutions of uranium, lead, and thorium ions: Anal. Chemistry, vol. 26 (November).

(8) Sandell, E。B. (1944) Colorimetric determination of traces of metals, New York, Interscience Publishers, p. 40.

(9) Weigert, Fritz (1916) Über absorptionsspektren und über eine enfache methode zu ihrer quantitativen bestimmung: Ber., v. 49 (1), p. 14961532, c.f., p。1525-1532 "Spektrophotometrische behandlung chemischer fragen." 
(10) Weissburger, Arnold (1945) Physical methods of organic chemistry, V. 2, New York, Interscience Publishers, p. 1298-1299.

(11) Willard, Hobart $H_{0}$, and Horton, Charles A. (1950), Indicators for titration with thorium: Anal. Chemistry, V. 22, p. 1190-1194.

(12) Vosburg, Warren C., and Cooper, Gerald R. (1941) Complex ions I. The identification of complex ions in solution by spectrophotometric measurements: Am. Chem. Soc. Jour., $v_{0} 63, p_{0} 437.442$. 


\section{APPENDIX}

Table 4.-Apparent equilibrium constant with the morin concentration the same for a.1 solutions $\left(3.548 \times 10^{\text {m5 }}\right.$ moles per liter) and the concentration of thorium varying.

\begin{tabular}{|c|c|c|c|c|}
\hline \multirow{2}{*}{ Number } & \multirow{2}{*}{$\begin{array}{l}\text { Absorbance } \\
\text { at } 410 \mathrm{~m} / 4 \\
1-\mathrm{cm} \text { ce } 11\end{array}$} & \multicolumn{2}{|c|}{ Components origina11y added } & \multirow{2}{*}{$\begin{array}{l}\text { Apparent } \\
\mathrm{K}_{\text {equilibrium }}\end{array}$} \\
\hline & & $\begin{array}{l}\text { Moles morin } \\
\text { per liter }\end{array}$ & $\begin{array}{c}\text { Moles thorium } \\
\text { per liter }\end{array}$ & \\
\hline 1 & 0.020 & $3.548 \times 10^{-5}$ & 0 & $\infty$ \\
\hline 2 & .140 & do. & $0.3809 \times 10^{-5}$ & $0.4850 \times 10^{6}$ \\
\hline 3 & .238 & do. & $0.7617 \times 10^{105}$ & $0.4268 \times 10^{6}$ \\
\hline 4 & .336 & do. & $1.170 \times 10^{-5}$ & $0.4831 \times 10^{6}$ \\
\hline 5 & .401 & do. & $1.523 \times 10^{m 5}$ & $0.6072 \times 10^{6}$ \\
\hline 6 & .456 & do. & $1.904 \times 10^{-5}$ & $0.6944 \times 10^{6}$ \\
\hline 7 & .492 & do. & $2.285 \times 10^{-5}$ & $0.7262 \times 10^{6}$ \\
\hline 8 & .540 & do. & $3.047 \times 10^{-15}$ & $0.7837 \times 10^{6}$ \\
\hline 9 & .575 & do. & $3.809 \times 10^{-5}$ & $0.8921 \times 10^{6}$ \\
\hline 10 & .638 & do. & $7.617 \times 10^{-5}$ & $1.065 \times 10^{6}$ \\
\hline 11 & .688 & do. & $15.235 \times 10^{-5}$ & $2.114 \times 10^{6}$ \\
\hline 12 & .716 & do. & $30.470 \times 10^{-5}$ & $5.747 \times 10^{6}$ \\
\hline 13 & .730 & do. & $60.939 \times 10^{-5}$ & $25.641 \times 10^{6}$ \\
\hline 14 & .740 & do. & $116.99 \times 10^{\infty 5}$ & $\begin{array}{c}\text { (omitted from average } \\
--\end{array}$ \\
\hline 15 & .740 & do. & $228.52 \times 10^{-5}$ & $\infty$ \\
\hline 16 & .740 & do. & $380.87 \times 10^{-5}$ & $\infty$ \\
\hline Average & $\ldots .$. & & $\cdots$ & $1.28 \times 10^{6}$ \\
\hline
\end{tabular}


Table 5. - Apparent equilibrium constant with the thorium concentration the same for a.11 solutions $\left(0.3809 \times 10^{\text {wis }}\right.$ moles per liter) and the concentration of morin varying.

\begin{tabular}{|c|c|c|c|c|}
\hline \multirow[b]{2}{*}{ Number } & \multirow{2}{*}{$\begin{array}{c}\text { Absorbance } \\
\text { at } 405 \mathrm{~m} / \\
5-\mathrm{cm} \mathrm{cel1} \\
\end{array}$} & \multicolumn{2}{|c|}{ Components originally added. } & \multirow{2}{*}{$\begin{array}{c}\text { Apparent } \\
\mathrm{K}_{\text {equilibrium }}\end{array}$} \\
\hline & & $\begin{array}{l}\text { Moles morin } \\
\text { per liter }\end{array}$ & $\begin{array}{l}\text { Moles thorium } \\
\text { per liter }\end{array}$ & \\
\hline 1 & 0.006 & 0 & $\rightarrow \infty$ & \\
\hline 2 & .064 & $0.1774 \times 10^{-55}$ & $0.3809 \times 10^{-5}$ & $6.378 \times 10^{6}$ \\
\hline 3 & .127 & $.3548 \times 10^{-5}$ & do. & $3.425 \times 10^{6}$ \\
\hline 4 & .187 & $.5322 \times 10^{-5}$ & do。 & $2.274 \times 10^{6}$ \\
\hline 5 & .246 & $.7096 \times 10^{-5}$ & do. & $1.934 \times 10^{6}$ \\
\hline 6 & .321 & $.9461 \times 10^{-5}$ & do. & $1.582 \times 10^{6}$ \\
\hline 7 & .343 & $1.064 \times 10^{-5}$ & do. & $1.317 \times 10^{6}$ \\
\hline 8 & .376 & $1.283 \times 10^{-55}$ & do. & $1.238 \times 10^{6}$ \\
\hline 9 & .386 & $1.301 \times 10^{105}$ & do. & $0.9930 \times 10^{6}$ \\
\hline 10 & .449 & $1.537 \times 10^{-5}$ & do. & $.9506 \times 10^{6}$ \\
\hline 11 & .472 & $1.774 \times 10^{-5}$ & do. & $.7215 \times 10^{6}$ \\
\hline 12 & .504 & $2.010 \times 10^{-5}$ & do. & $.6173 \times 10^{6}$ \\
\hline 13 & .538 & $2.247 \times 10^{-55}$ & do. & $.5540 \times 10^{6}$ \\
\hline 14 & .553 & $2.365 \times 10^{-5}$ & do. & $.5263 \times 10^{6}$ \\
\hline 15 & .591 & $2.661 \times 10^{\infty 5}$ & do. & $.4792 \times 10^{6}$ \\
\hline 16 & .691 & $2.957 \times 10^{-5}$ & do. & $.4228 \times 10^{6}$ \\
\hline 17 & .641 & $3.548 \times 10^{-5}$ & do. & $.2768 \times 10^{6}$ \\
\hline 18 & .698 & $4.730 \times 10^{-5}$ & do. & $.1605 \times 10^{6}$ \\
\hline 19 & .782 & $5.913 \times 10^{-5}$ & do. & $.1379 \times 10^{6}$ \\
\hline 20 & .860 & $7.096 \times 10^{-5}$ & do. & $.1322 \times 10^{6}$ \\
\hline Average & $\cdots$ & & & $1.27 \times 10^{6}$ \\
\hline
\end{tabular}


Table 6.-Apparent equilibrium constant with the concentration of thorium and morin both varying continuously. Total moles

Th + morin constant.

\begin{tabular}{|c|c|c|c|c|}
\hline \multirow[b]{2}{*}{ Number } & \multirow[b]{2}{*}{$\begin{array}{l}\text { Absorbance } \\
\text { at } 410 \mathrm{~m} / \\
1 \text { - cm cell. }\end{array}$} & \multicolumn{2}{|c|}{ Components originaliy added } & \multirow[b]{2}{*}{$\begin{array}{c}\text { Apparent } \\
\mathrm{K}_{\text {equilibrium }}\end{array}$} \\
\hline & & $\begin{array}{l}\text { Moles morin } \\
\text { per liter }\end{array}$ & $\begin{array}{c}\text { Moles thorium } \\
\text { per liter }\end{array}$ & \\
\hline 1 & 0.023 & $-\infty$ & $\infty$ & $-\infty$ \\
\hline 2 & .198 & $5.46 \times 10^{-5}$ & $0.540 \times 10^{-5}$ & $0.1969 \times 10^{6}$ \\
\hline 3 & .240 & $5.32 \times 10^{-5}$ & $.680 \times 10^{-5}$ & $.2191 \times 10^{6}$ \\
\hline 4 & .282 & $5.18 \times 10^{05}$ & $.820 \times 10^{-3}$ & $.2415 \times 10^{\circ}$ \\
\hline 5 & .321 & $5.04 \times 10^{-5}$ & $.960 \times 10^{-5}$ & $.2698 \times 10^{6}$ \\
\hline 6 & .338 & $4.90 \times 10^{-5}$ & $1.10 \times 10^{-5}$ & $.2237 \times 10^{8}$ \\
\hline 7 & .396 & $4.76 \times 10^{-5}$ & $1.24 \times 10^{.5}$ & $.3549 \times 10^{6}$ \\
\hline 8 & .424 & $4.62 \times 10^{-5}$ & $1.38 \times 10^{\circ 5}$ & $.3792 \times 10^{6}$ \\
\hline 9 & .451 & $4.48 \times 10^{-5} 5$ & $1.52 \times 10_{-5}^{-5}$ & $4281 \times 10^{6}$ \\
\hline 10 & .473 & $4.34 \times 10^{-5}$ & $\times 10^{-5}$ & $.4660 \times 10^{6}$ \\
\hline 11 & .487 & $4.20 \times 10^{-5}$ & $1.80 \times 10^{.55}$ & $.5128 \times 10^{6}$ \\
\hline 12 & .489 & $4.06 \times 10^{-5}$ & $1.94 \times 10^{0.5}$ & $.5023 \times 10^{6}$ \\
\hline 13 & .501 & $4.00 \times 10^{-5}$ & $\times 10^{=5}$ & $.5727 \times 10^{6}$ \\
\hline 14 & .505 & $3.92 \times 10^{-5}$ & $2.08 \times 10^{-5}$ & $.6010 \times 10^{6}$ \\
\hline 15 & .497 & $3.78 \times 10^{-5}$ & $2.22 \times 10^{-5}$ & $.5814 \times 10^{6}$ \\
\hline 16 & .500 & $3.64 \times 10^{-5}$ & $2.36 \times 10^{-5}$ & $.6562 \times 10^{6}$ \\
\hline 17 & .495 & $3.50 \times 10^{-5}$ & $2.50 \times 10^{-5}$ & $.7057 \times 10^{6}$ \\
\hline 18 & 481 & $3.36 \times 10^{-5}$ & $2.64 \times 10^{-5}$ & $.6863 \times 10^{\circ}$ \\
\hline 19 & .478 & $3.22 \times 10^{=5}$ & $2.78 \times 10^{\circ 5}$ & $.8097 \times 10^{6}$ \\
\hline 20 & .462 & $3.08 \times 10^{-5}$ & $\times 10^{-5}$ & $.8091 \times 10^{6}$ \\
\hline 21 & .434 & $2.80 \times 10^{-5}$ & $\times 10^{-5}$ & $.9285 \times 10^{6}$ \\
\hline 22 & .420 & $2.66 \times 10^{-5}$ & $810^{-05}$ & $1.042 \times 10^{6}$ \\
\hline 23 & .402 & $2.52 \times 10^{-5}$ & $x \cdot 10^{=0-5}$ & 1.089 \\
\hline 24 & .323 & $1.96 \times 10^{-5}$ & $\times 10_{-5}^{-5}$ & 1.440 \\
\hline 25 & .290 & $1.68 \times 10^{-5}$ & $\times 10^{-5}$ & 2.390 \\
\hline 26 & .197 & $1.12 \times 10^{-55}$ & $4.88 \times 10^{-5}$ & 3.675 \\
\hline 27 & .103 & $.56 \times 10^{\infty 5}$ & $5.48 \times 10^{-5}$ & $11.820 \times 10^{\circ}$ \\
\hline
\end{tabular}

Average

$1.22 \times 10^{6}$ 
Table 7.--Apparent equilibrium constant with the concentrations of morin, thorium, and total moles $T h+$ morin all varying continuously。

\begin{tabular}{|c|c|c|c|c|}
\hline \multirow[b]{2}{*}{ Number } & \multirow[b]{2}{*}{$\begin{array}{l}\text { Absorbance } \\
410 \mathrm{~m} / \mathrm{h} \\
2-\mathrm{cm} \text { cell }\end{array}$} & \multicolumn{2}{|c|}{ Components originally added } & \multirow[b]{2}{*}{$\begin{array}{c}\text { Apparent } \\
\mathrm{K}_{\text {equilibrium }}\end{array}$} \\
\hline & & $\begin{array}{l}\text { Moles morin } \\
\text { per liter }\end{array}$ & $\begin{array}{l}\text { Moles thorium } \\
\text { per liter }\end{array}$ & \\
\hline 1 & 0.039 & $5.60 \times 10^{0.5}$ & 0 & - \\
\hline 2 & .730 & $5.46 \times 10^{-5}$ & $1.08 \times 10^{-5}$ & $0.2545 \times 10^{6}$ \\
\hline 3 & .870 & $5.32 \times 10^{-5}$ & $1.36 \times 10^{-5}$ & $.2778 \times 10^{6}$ \\
\hline 4 & 1.000 & $5.18 \times 10^{-5}$ & $1.64 \times 10^{-5}$ & $.3234 \times 10^{6}$ \\
\hline 5 & 1.092 & $5.04 \times 10^{-5}$ & $1.92 \times 10^{-5}$ & $.3460 \times 10^{6}$ \\
\hline 6 & 1.190 & $4.90 \times 10^{-5}$ & $2.20 \times 10^{-5}$ & $.4237 \times 10^{6}$ \\
\hline 7 & 1.239 & $4.76 \times 10^{-5}$ & $2.48 \times 10^{-5}$ & $.4525 \times 10^{6}$ \\
\hline 8 & 1.0271 & $4.62 \times 10^{-5}$ & $2.76 \times 10^{-5}$ & $.4902 \times 10^{6}$ \\
\hline 9 & 1.294 & $4.48 \times 10^{-5}$ & $3.04 \times 10^{-5}$ & $.5435 \times 10^{6}$ \\
\hline 10 & 1.280 & $4.34 \times 10^{-5}$ & $3.32 \times 10^{-5}$ & $.5291 \times 10^{6}$ \\
\hline 11 & 1.279 & $4.20 \times 10^{-5}$ & $3.60 \times 10^{-5}$ & $.5780 \times 10^{6}$ \\
\hline 12 & 1.272 & $4.06 \times 10^{-5}$ & $3.88 \times 10^{-5}$ & $.6329 \times 10^{6}$ \\
\hline 13 & 1.268 & $4.00 \times 10^{-5}$ & $4.00 \times 10^{\infty 5}$ & $.6711 \times 10^{6}$ \\
\hline 14 & 1.249 & $3.92 \times 10^{-5}$ & $4.16 \times 10^{-5}$ & $.6579 \times 10^{6}$ \\
\hline 15 & 1.217 & $3.78 \times 10^{-5}$ & $4.44 \times 10^{-5}$ & $.6623 \times 10^{5}$ \\
\hline 16 & 1.192 & $3.64 \times 10^{-5}$ & $4.72 \times 10^{-5}$ & $.7194 \times 10^{6}$ \\
\hline 17 & 1.173 & $3.50 \times 10^{-5}$ & $5.00 \times 10^{-5}$ & $.8403 \times 10^{6}$ \\
\hline 18 & 1.125 & $3.36 \times 10^{-5}$ & $5.28 \times 10^{-5}$ & $.7937 \times 10^{6}$ \\
\hline 19 & 1.098 & $3.22 \times 10^{-5}$ & $5.56 \times 10^{-5}$ & $.9174 \times 10^{6}$ \\
\hline 20 & 1.061 & $3.08 \times 10^{-5}$ & $5.84 \times 10^{-5}$ & $1.004 \times 10^{6}$ \\
\hline 21 & .965 & $2.80 \times 10^{-5}$ & $6.40 \times 10^{-5}$ & $.9615 \times 10^{6}$ \\
\hline 22 & .779 & $2.24 \times 1.0^{-5}$ & $7.52 \times 10^{-5}$ & $1.056 \times 10^{6}$ \\
\hline 23 & .610 & $1.68 \times 10^{-5}$ & $8.64 \times 10^{-5}$ & $2.045 \times 10^{6}$ \\
\hline Average & & & & $0.699 \times 10^{6}$ \\
\hline
\end{tabular}

